\title{
Politeness Strategies in the Main Characters of "The Devil Wears Prada" Movie
}

\section{Strategi Kesopanan yang diterapkan oleh Karakter Utama Film "The Devil Wears Prada"}

\author{
Nadia Probosini \\ Universitas Diponegoro, Jl. Erlangga Barat No. 7 Semarang, Jawa Tengah \\ e-mail: nadiaprobosini@gmail.com
}

\begin{abstract}
This research was an interpersonal communication study on politeness strategies employed by the main characters in Devil Wears Prada movie in the context of workplace communication. This research aimed to explain politeness strategies employed by the main characters of The Devil Wears Prada movie. This was qualitative research, and the data were utterances of the three main characters containing politeness strategies. The source of the data was the script of Devil Wears Prada movie, and it was found that 135 politeness strategies occurred. It was: Bald On Record (47 times), Positive Politeness (49 times), Negative Politeness (19 times), and Off Record (20 times). The findings demonstrated that positive politeness strategies were the most frequent strategies in this movie. It indicated that the main characters tended to use positive politeness to show their respect and that they have a harmonious relationship in the workplace.
\end{abstract}

Keywords: Devil Wears Prada; Interpersonal Communication; Politeness Strategies; Work-Life

\begin{abstract}
Abstrak
Penelitian ini adalah studi komunikasi interpersonal tentang strategi kesopanan yang digunakan oleh pemeran utama dalam film Devil Wears Prada dalam konteks komunikasi di tempat kerja. Tujuan dari penelitian ini adalah (1) untuk menggambarkan model wacana kesopanan yang dilakukan oleh pemeran utama dalam Film Lauren Weisberger: "The Devil Wears Prada" (2) untuk menganalisis bagaimana strategi kesopanan menurut konsep Brown dan Levinson direalisasikan oleh pemeran utama dalam Film Lauren Weisberger: "The Devil Wears Prada". Penelitian ini adalah penelitian kualitatif. Data tersebut dalam bentuk ucapan oleh tiga pemeran utama yang berisi strategi kesopanan. Sumber data adalah naskah film Devil Wears Prada. Pada awalnya, penulis membaca semua naskah dan kemudian mengidentifikasi dan menganalisis dialog yang berisi strategi kesopanan. Hasil dari penelitian ini menunjukkan bahwa ada 135 strategi kesopanan yang terjadi: Bald On Record (47 kali), Politeness Positif (49 kali), Politeness Negatif (19 kali), dan Off Record (20 kali). Oleh karena itu, dapat disimpulkan bahwa strategi positive politeness adalah strategi yang paling sering dalam film ini. Ini menunjukkan bahwa pemeran utama cenderung menggunakan positive politeness untuk menunjukkan rasa hormat mereka dan menunjukkan bahwa mereka memiliki hubungan yang baik karena situasinya ada di tempat kerja.
\end{abstract}

Kata Kunci: Film; Komunikasi Antarpribadi; Strategi Kesopanan; Tempat Kerja 


\section{Introduction}

There are two types of communication: direct (face-to-face) and indirect communication (through media), and, as a rule, human beings communicate with each other by conducting conversations. In communication through conversation, each actor use language to express her opinion and idea, but frequently conversations witness undesirable outcomes because of miscommunication happened among communicators. Building up their communication quality with proper language and make their language respectful, therefore, is essential. One of the ways to realize that issue is by exercising suitable strategies to talk appropriately and having manner during the talk, or, in short, by being polite. According to Hornby (Fauzi, 2010), politeness is mainly associated with listening and having a decent attitude and manner. A human could shape and polish the language to represent the polite behavior and attitude, and, therefore, in interaction, politeness strategy plays a significant role to relate with other people.

Schein (1989) observed that Goffman wrote about both human faces and how people interact in their daily lives. For him, not only do humans act socially and keep their identity, but they also create faces for other humans. This idea is highly linked with politeness, as politeness signifies the level of acts that should be carried out by individuals. People should decide how to appropriately behave with situations and enable the communicants and communicators to experience comfort during the conversation. Being polite, thus, is not merely a matter of correctness and conformity since politeness has its own identity. Politeness study, therefore, is a study on the interaction methods for both establishing and preserving ones' interpersonal relations, where an interpersonal relationship is defined as communication about personal lives between two individuals.

Furthermore, politeness includes a set of behaviors that can demonstrate ones' thoughtfulness towards other people's feelings about how they should be treated. Being mindful of the interlocutor's education, age, social class, sex, personality, and background is necessarily essential for being polite (Wright, 2004). For example, in the workplace, where communication between the directors and employee occur daily, formal language is deemed acceptable since the situation is formal. It is different if people talk casually with their friends. Informal style is preferable, and precise rules can be ignored except for specific circumstances.

This research focuses on politeness consideration in the workplace introduced by a movie. This research aims to understand workplace management, which is more effective in the workplace. A movie was chosen as it is effective media to deliver understanding, including politeness strategy. As stated by Farady (2016), a movie was a part of mass media communication that provides both entertainment and information, whether educational or persuasive.

Several studies have been conducted relating to this topic. Firstly, a study entitled "Gender and Politeness in a Foreign Language Academic Context" by Bacha (Bacha, 2012). This study motivated the need to scrutinize what is considered polite in the classroom by students to upscale class management at Lebanese American University. This study attempted to analyze the reaction of men and women in the academic environment of universities and how far they could find a pleasant class atmosphere. This study showed that cultural issues are more significant in triggering misunderstanding regarding impoliteness between genders among students than the impoliteness itself.

Another research is a study entitled "Politeness Strategy Employed by Deddy Corbuzier in Interviewing Celebrities and Non-celebrities in the Hitam Putih Talk Show," written by Pangestuti (Pangestuti, 2015). This research aimed to analyze the types of 
politeness strategy executed by Deddy Corbuzier in interviewing celebrity and noncelebrity. The analysis found different types of strategy and reason performed by the host. Deddy Corbuzier used Sixteen politeness strategies during the interview, and there were six differences in the strategy used when interviewing celebrities and non-celebrities.

Against that background, interaction in the workplace is a crucial object. The reason is that activities in the worksite are familiar with interpersonal communication. Communication between the employer and the employee, and among employees are some of the examples. The research intended to understand and explain the politeness strategies employed by the main character in The Devil Wears Prada movie, a movie adapted from Lauren Weisberger's novel. This movie was picked as the subject-matter as it contains elements and utterances required to analyze politeness strategies, which spread from the dialog, character, to settings. Also, because this movie has been internationally recognized, this movie has reached a reasonably high familiarity with the general public. A movie is chosen for this strategy since, apart from the simplicity to be absorbed by society because people typically are keen on watching movies, the situation or context of utterance appears dominantly in most movies. It enables politeness strategies to be examined adequately.

This research applies a theoretical model initiated by Brown and Levinson, which considers face concept to define politeness. In the framework, although each community has its distinct norm for identifying appropriate behaviors, and that norm is varied, politeness itself is universal, and it originates from the needs of the human face (Blutner, 2016).

Politeness, as defined by the researcher, is a basis to produce social fabric and partnership among humans. Consequently, theories that explain this phenomenon explain the foundation of social lives as well. According to Zahar (2012), politeness is one of the aspects of interaction that is useful for producing respect towards other individuals. By emitting politeness elements in communication, people could knit social relationships, together with respecting their images. In line with that concept, Brown and Levinson (1987) stated that politeness is reflected in language. Each community, apart from the level of its isolation or social-economic complexity, shows similar principles in the workplace. However, what is not considered polite probably different from one community to another, one situation to another, or from individual to another individual (Blutner, 2016).

Brown and Levinson offered descriptive analysis strategies to analyze subjects that keep their faces in social interaction. According to Bousfield (2008: 57-59) in Hasmi (2013), Brown and Levinson summarized politeness in five strategies: bald on record, positive politeness, negative politeness, off record, and no FTA.

\section{a) Bald on Record}

Bald on record is a strategy to move directly to the core concept of conversation. This strategy does not minimize threats to the hearer's face. The speakers immediately state what they wish to the interlocutor. This strategy is the most effective way to a void miscommunication, although it is deemed not polite since it threatens the interlocutor's face. Brown and Levinson (1987) explained that the reason to use this method is that $S$ (speaker) prefer efficiency than satisfying H's (hearer) face.

\section{b) Positive Politeness}

Positive politeness is an attempt to balance interlocutor's positive face by attempting that the speaker share wish, or actions, acquisitions, values similar to the 
hearer. Balancing that is considered here is satisfying the hearers' wish by showing that the wish of the speaker is similar to the receiver's wish. Generally, it is found in a group of friends that try to minimize distance among them by uttering correctness and a strong passion to the hearer that they are deserved to be respected (minimizing FTA).

\section{c) Negative Politeness}

Negative politeness is restorative action targeting hearers that have negative faces. This strategy aims to make the hearer act freely without avoiding attention. Typically, this strategy is used when distance and formality appear in the conversation between the speaker and the hearer.

\section{d) Off records}

Off record strategy can be performed when the $\mathrm{S}$ wishes to perform FTA but by avoiding responsibility to do the action. This strategy uses indirect language and, to apply this strategy, the speaker could choose expressions that are more general or different from what is intended.

\section{e) Do not do the FTA}

This strategy states that $\mathrm{S}$ avoid any action that can offend $\mathrm{H}$. Consequently, $\mathrm{S}$ will fail to reach its intended communication.

\section{Methodology}

According to Arikunto (2010: 20), based on its way to collect and examine data, research could be split into qualitative and quantitative research. While the former explores ideas, reasons, and opinions carefully by retrieving descriptive data from interviews, videos, notes, and other similar sources, the latter deal with numerical data, including variables and hypotheses to constitute research questions that will be formulated into statistics.

This research was descriptive qualitative research that was supported by quantitative analysis. In this research, the researcher explained ideas, opinions, and analyses of the topic individually. The statements then were analyzed using Brown and Levinson's theory of politeness. while the tendency of politeness strategy appearing in the movie was examined with the quantitative method. The data was collected from Devil Wears Prada's dialog, notably concerning politeness strategies among the main characters and leaders. The dialog was retrieved from https://subscene.com/subtitles/the-devilwears-prada/english/1634700.

\section{Results and Discussion}

As reported in table 4.1, there are 135 politeness strategies found, in which positive politeness was the most frequent one. The main characters preferred using positive politeness to show their respects toward others. With that strategy, they also wanted to share similarities with the hearer. This strategy used 49 times, compared to bald on record ranked in the second position with 47 times. Following this is off record and negative politeness with 20 times and 19 times respectively.

Table 1. Types of Politeness Strategy

\begin{tabular}{cccc}
\hline \multirow{2}{*}{ No } & \multirow{2}{*}{ Politeness Strategy } & \multicolumn{2}{c}{ Result } \\
\cline { 3 - 4 } & Bald On Record & Frequency & Percentage (\%) \\
\hline 1 & Positive Politeness & 47 & 35 \\
\hline 2 & Negative Politeness & 49 & 36 \\
\hline 3 & Off Record & 19 & 14 \\
\hline 4 & & 20 & 15 \\
\hline
\end{tabular}




\section{Realization of Politeness Strategy in the Main Characters Utterances}

Based on Brown and Levinson theory (1987), the realization of politeness strategy is presented as follows:

\section{Bald On Record}

Citation 36-47

00:06:59 $\rightarrow$ 00:07:14

Miranda: Call my ex and remind him the parent-teacher conference is at Dalton. Then call my husband, ask him to meet me for dinner at that place I went to with Massimo. Tell Richard I saw the pictures he sent for that feature on female paratroopers, and they're all so unattractive.

The situation is about Miranda that come earlier to the office. Everyone is in a hurry due to Miranda's presence. Emily runs to the lift waiting for Miranda, and she follows Miranda by holding her coat. After that, Miranda asks anything she wants. Miranda is amazing. She always delegates numerous tasks at the same time to her assistant. However, she merely gives direction once without clarification, and Emily always notes down any task assigned by Miranda. Miranda uses words such as "call him" or "tell him" to show that she is giving orders. The situation above showed that a person with a higher position could give an order or perform bald on record.

\section{Citation 66-67}

00:08:00 $\rightarrow$ 00:08:04

Emily: This is foul. Don't let her see it.

Andrea: That's my...

Emily: Go.

It was a situation when Emily holds Andrea's bag that is unusual. The bag is not for show in front of Miranda when the second assistant is interviewed because Runway is everything in terms of fashion. Emily says, "go" to remind Andrea not to be sluggish and slow-response in front of Miranda. They should be fast and responsive. Word "no" in the citation is to show that Emily, as her partner, asks Andrea not to bring the awful bag. She also uses "go" as a farewell in bald on record.

Two citations above demonstrated that leaders, towards their subordinates, could perform bald on record because the leaders own authorities to give direct and clear order for efficiency. However, this condition can also be used in an emergency, as shown in the second dialog.

\section{Positive Politeness}

There are some politeness sub-strategies executed by the main characters, as illustrated as follows:

\section{Claiming Common Ground}

This sub-strategy depicted that the speakers and hearers have the same intentions and goals. The following are some citations containing positive politeness.

\section{Exaggerate (Interest, Approval, Sympathy with Hearer)}

Citation 615-617

00:42:18 $\rightarrow$ 00:42:28

Andrea: Hi.

Christian: Christian Thompson. 
Andrea: Christian Thompson? You're kidding. No, you're... You write for, like, every magazine I love.

It was a situation after Andrea goes to James Holt's party to take Miranda's catalog. Unexpectedly, Christian approaches her, and they introduce each other. Andrea is thrilled to know that she could be acquainted with her favorite author. The expression: "no, you're... You write for, like, every magazine I love" represented that Andrea exaggeratedly used positive politeness, which means that Andrea admires Christian.

\section{Intensify Interest to Hearer \\ Citation 999-1002}

01:11:59 $\rightarrow$ 01:12:12

Emily: Do you know what really just gets me about this whole thing? Is that, you know, you're the one who said that you don't really care about this stuff. You don't really care about fashion; you just want to be a journalist.

Emily is irritated by Andrea because she is the one who was picked as the delegation to go to Paris with Miranda. Paris is Emily's dream, and she genuinely has sacrificed her life only to go to Paris for a year. Miranda then switched Emily with Miranda to accompany her to Paris since Andrea is deemed by Miranda to be more reliable. Not to mention that Emily is suffering from cold. Emily envies Andrea. These words: "Do you know what really just gets me about this whole thing? Is that, you know, you're the one who said that..." was used to escalate the hearer's attention by giving a statement that is unanswerable for the hearer. Emily wants Andrea to know that Emily is mad at Andrea.

\section{Presuppose/raise/assert common ground}

Citation 926-927

01:04:18 $\rightarrow$ 01:04:24

Christian: Thank God I saved your job.

Andrea: Okay. You know, I figured out_a few things on my own too.

Andrea gets a very demanding task from Miranda; namely, she has to find the latest Harry Potter manuscripts for the twins, and she only has three hours to find it. If she cannot fulfill the task, she will be fired by Miranda. After trying for quite a long time, Andrea still cannot find the manuscript. Andrea then decides to call Christian, and she hopes that he is in contact with JK Rowling, seeing that they are writers. After Christian helps Andrea, they meet in Miranda's spring fashion show. Christian assumes that he is the savior. Andrea uses these words, "you know...", meaning that Christian has known on how hard she strives for Miranda before asking for his help.

\section{Offer, Promise}

Citation 602-604

James: Here we go. It's a sketch of Miranda's dress for the benefit. Also the centerpiece of my spring collection. Top-secret stuff.

Andrea: I'll guard it with my life.

Andrea is tasked with Miranda to take James Holt's catalog in a particular place. After they meet, James observes Andrea's gesture in bringing the catalog as it is replete with secret contents. Andrea promises to protect the catalog with her life, meaning that Andrea will keep the catalog decently, and it is included in the promise expression in positive politeness. 
Based on the dialogs above, which contain positive politeness, FTA performed by the speaker in the utterance threatened the positive face of the speaker. The reason is that the speaker intended the hearer to have the same opinion to produce solidarity.

\section{Negative Politeness \\ Be Direct \\ Be Conventionally Indirect \\ Citation 190}

00:15:14 $\rightarrow$ 00:15:18

Andrea: You know; she is in a meeting. Could I please take a message?

As Miranda's second assistant, one of Andrea's task is being a desk officer. She is on her table for the whole day. If she is not there, there might be a call for Miranda. Andrea used negative politeness by saying these words: "Could I please take a message?" That word was a softer version of "is there something you want to say to her?"

\section{Don't Presume or Assume \\ Question, Hedge \\ Citation 465-467}

$00: 31: 21 \rightarrow 00: 31: 35$

Miranda: Anyway, you ended up disappointing me more than any of the other silly girls.

Andrea: I really did everything I could think of.

Miranda's flight from Miami to New York was delayed because of a storm. Then, Miranda asked Andrea to find a jet plane to come back to her house in the evening. She has to attend the twin's show in their school recital. Andrea cannot fulfill it since it is out of her capability. No jet could fly that evening because of the weather. Miranda is mad at Andrea and guilty to her children because they must be disappointed. Andrea used a substrategy question and value protection by using words, such as "really," and "I think" to suggest certainty.

\section{Don't coerce $H$ \\ Be Pessimistic \\ Citation 192-193}

00:15:23 $\rightarrow$ 00:15:26

Andrea: Can you please spell «Gabbana»? Hello?

In that situation, Andrea, as a new assistant, is tasked to receive calls from Miranda. She cannot listen to what the speaker talks about so that she asks the company's name to the speaker, and she will note it down for Miranda. However, Gabbana's staff hang the telephone up. Andrea used negative politeness in being pessimistic by saying, "please do X ..." It showed that the speaker asked the hearer to do an activity, but at the same time, the speaker was hesitant whether his action appropriate.

Communicate $S$ 's want to not impinge on $\mathrm{H}$

Apologizing

Citation 1245

01:31:18 $\rightarrow$ 01:31:21

Andrea: Mr. Ravitz, I'm so sorry to bother you, but I was wondering... 
The text above was when Andrea finds out that Jacqueline will replace Miranda's position as the head of Rumway magazine without Miranda's knowledge. He runs as fast as he can to Miranda's room and knocks the door without stopping until Mr. Ravits, Miranda's husband, opens the door. Andrea cannot end her sentences since Miranda is coming and closing the door. Andrea apologizes because of her utterances in "I'm so sorry to bother you" She wanted to show that she fully realized that her action was not polite, but that was necessary for she wanted to ask something to Mr. Ravits.

In that dialog, the speaker's FTA was shown on the negative self-image or negative face of the hearer. This is because the speaker disturbed the independence or freedom of the hearer in acting by asking the hearer to give information the speaker wants. This is a negative politeness strategy. The speaker also made utterances that are not directly connected to the forms and function of the aim of the utterance for the hearer's comfort and negative self-image.

\section{Off Records}

\section{Invite Conversational Implicatures}

People tend to use indirect speech when using FTA. The speaker uses utterances with secondary meaning to give a sign and hope that the hearer will understand her. It can be an indirect request or an indirect question.

\section{Give Hints}

Citation 449-451

00:30:20 $\rightarrow$ 00:30:32

Miranda: The girls' recital was absolutely wonderful. They played Rachmaninoff. Everyone loved it. Everyone except me, because, sadly, I was not there.

In the citation above, Miranda asks Andrea to find a jet for her because her flight was delayed out of bad weather. Miranda has to go home at that time since she has to attend her daughters' recital. Andrea cannot fulfill the request, and Miranda is disappointed. When she said: "everyone loved it. Everyone except me, because, sadly, I was not there," showed that she used off record strategy in general and gave hints in particular. Implicitly, it can mean: "I cannot go to my daughter's recital because you cannot fulfill my request. You cannot fulfill your task excellently as well."

\section{Use Rhetorical Question \\ Citation 203}

00:16:00 --> 00:16:04

Miranda: There you are, Emily. How many times do I have to scream your name?

The citation was about when Miranda calls Andrea with Emily's name. She does not know that Miranda is calling her until Nigel gives a signal to Andrea that it is her. Miranda used a rhetorical question in off record situation by saying, "How many times do I..."

The utterance showed that this strategy was used indirectly to give an ambiguous sense of communication. In other words, the speakers wanted to do FTA altogether by avoiding the responsibility of her action. Consequently, the hearer should interpret the meaning of the words. It could mean not only one thing but also insinuation.

\section{Conclusion}


After analyzing the data, the research has demonstrated that the main characters used bald on record strategy for 47 times $(35 \%)$ while positive politeness for 49 times (36\%). Negative politeness happened 18 times (14\%) and off record 20 times (16\%). Positive politeness was the most used strategy by the main characters. It indicates that the main characters tended to use positive politeness to show their respects and that they had a decent relationship, mostly because they were in the workplace. Bald on record was frequently found among coworkers. Mostly it happened between the head and the subordinates in the workplace, as shown in the movie.

In realizing the politeness strategy, neither Andrea Sachs nor Emily exercised positive politeness towards older people or people who had a higher position in the social hierarchy. Andrea Sachs was likely to use positive politeness to show closeness with the interlocutor and that she intended to have a genuine relationship with the hearer. Emily Chartlon, on the other hand, preferred to exercise bald on record than other strategies, mainly when they talked with Andrea, as her partner. He used bald on record to utter something directly without avoiding FTA. The reason is that they were reasonably close to performing that.

Miranda Priestly often employed bald on record to her assistants. It showed that the higher the position, the more significant her privilege to ask something using direct sentences. Furthermore, Miranda inclined to use indirect sentences or off record to the assistants. In this vein, Miranda compelled her assistant to interpret the real meaning of what she is talking about. The analysis has demonstrated that the main characters were in favor of positive politeness since the speaker often showed respects. Furthermore, it can be used to show that they have a harmonious relationship in the workplace.

\section{References}

Arikunto, Suharsimi. (2010). Prosedur Penelitian Suatu Pendekatan Praktik. Jakarta: Rineka Cipta.

Bacha, Nahla Nola. (2012). Gender and Politeness in a Foreign Language Academic Context. Research Paper. Lebanese American University. Lebanon.

Blunter, Reinhard. (2016). Politeness: Some Universals in Language Usage. Journal: STUF - Language Typology and Universals

Brown \& Levinson. (1987). Politeness Some Universals in Language Usage. Cambridge: Cambridge University Press.

Escandell, Victoria. (1998). Politeness: A Relevant Issue for Relevance Theory, Revista Alicantina de Esruaios Ingleses, 45-57. Research Paper. UNED. Madrid.

Farady, Rustono. (2016). Dampak Kekuatan Informasi Film Ngenest Terhadap Penilaian Komunitas Stand Up di Jakarta. Jurnal ASPIKOM.

Fauzi, Muhammad Ihsan. (2010). A Politeness Strategy Analysis on the Main Characters' Dialogs of the Movie Pirates of Carribean: Dead Man's Chest. Jakarta: Syarif Hidayatullah State Islamic University.

Goffman, E. (1959). The Presentation of Self in Everyday Life. Garden City, New York: Doubleday.

Hasmi, Mifta. (2013). A Pragmatic Analysis of Politeness Strategies Reflected in Nanny McPhee Movie. Research Paper. Yogyakarta State University. Yogyakarta.

Hornby, AS. (2000). Oxford Advanced Learner's Dictionary. Sixth Edition. Oxford: Oxford University Press.

Kurniawan, Nurdy. (2015). An Analysis of Positive and Negative Politeness Strategies in 
an Interview of Mark Rutte on Metro Tv Face 2 Face With Desi Anwar Program. Research Paper. Syarif Hidayatullah State Islamic University. Jakarta.

Llamas, C., Mullany, L. \& Stockwell, P. (2007). The Routldge Companion To Sociolinguistics. Routledge: New York.

Nordquist, Richard. (2017). The Art of Communication. https://www.thoughtco.com/what-is-communication-1689877/, accessed on 30 October 2017.

Pangestuti, W. (2015). Politeness Strategies Used By Deddy Corbuzier in Interviewing Entertainer and Non Entertainer in Hitam Putih Talk Show. Research Paper. Diponegoro University. Semarang.

Purnamasari, Yesi. (2015). Politeness Strategies Used in the Graham Norton Show Broadcast on BBC One in September 30th 2016. Research Paper. Stikubank University. Semarang.

Schein, E.H. (1989). A Social Psychologist Discovers Chicago Sociology. Journal Academy Management View.

The Devil Wears Prada Movie Subtitle https://subscene.com/subtitles/the-devil-wearsprada/english/1634700, accessed on 20 October 2017.

The Politeness Theory: A Guide for Everyone https://www.universalclass.com/articles/business/communicationstudies/politeness-theory.htm, accessed on 30 October 2017.

Watts, R. J. 2003. Politeness. Cambridge: Cambridge University Press.

Wright, Sue. (2004). From Language Continuum to Linguistic Mosaic: European Language Communities from the Feudal Period to the Age of Nationalism. New York: Language Policy and Language Planning.

Zahar, Adrian Kurniawan. (2012). Strategi Kesopanan dalam Tindak Tutur Tak Langsung pada Film Harry Potter and the Deathly Hallows. Skripsi: Universitas Padjajaran. 